\section{Responses of Zinnia angustifolia $\times$ Z. violacea Backcross Hybrids to Three Pathogens}

\author{
Thomas H. Boyle \\ Department of Plant and Soil Sciences, French Hall, University of \\ Massachusetts, Amherst, MA 01003
}

\author{
Robert L. Wick \\ Department of Plant Pathology, Fernald Hall, University of Massachusetts, \\ Amherst, MA 01003 \\ Additional index words. Alternaria zinniae, Erysiphe cichoracearum, Xanthomonas \\ campestris pv. zinniae, Zinnia marylandica, ornamental plants, pest resistance
}

\begin{abstract}
True-breeding lines of Zinnia marylandica Spooner, Stimart \& Boyle [allotetraploids of $Z$. angustifolia H.B.K. and $Z$. violacea Cav. $(2 n=4 x=46)]$ were backcrossed with autotetraploid $Z$. angustifolia $(2 n=4 x=44)$ and $Z$. violacea $(2 n=4 x=48)$. Seed-generated, backcross $\left(\mathrm{BC}_{1}\right)$ families were screened for resistance to alternaria blight (Alternaria zinniae Pape), bacterial leaf and flower spot [Xanthomonas campestris pv.zinniae (Hopkins and Dowson) Dye], and powdery mildew (Erysiphe cichoracearum DC. ex Merat). All BC ${ }_{1}$ families exhibited high levels of resistance to alternaria blight and powdery mildew. $\mathrm{BC}_{1}$ families derived from crossing $Z$. marylandica with autotetraploid $Z$. angustifolia were highly resistant to bacterial leaf and flower spot, whereas $\mathrm{BC}_{1}$ families derived from crossing $Z$. marylandica with autotetraploid $Z$. violacea were susceptible to this disease. Our results suggest that one $Z$. angustifolia genome in $\mathrm{BC}_{1}$ allotetraploids is sufficient to confer resistance to $A$. zinniae and $E$. cichoracearum, but at least two $Z$. angustifolia genomes are required in $\mathrm{BC}_{1}$ allotetraploids to provide resistance to $X$. campestris pv. zinniae.
\end{abstract}

The common zinnia [formerly Z. elegans Jacq., currently Zinnia violacea (McVaugh, 1984)] is subject to attack by three major pathogens: Alternaria zinniae (alternaria blight), Erysiphe cichoracearum (powdery mildew), and Xanthomonas campestris pv. zinniae (bacterial leaf and flower spot) (Andersen, 1971; Jones and Strider, 1979; Lipschutz, 1965; Torres, 1963). These pathogens incite moderate to severe epiphytotics within $Z$. violacea plantings, resulting in plant losses, decreased ornamental value, or both. The narrow-leaved zinnia [Z. angustifolia (McVaugh, 1984)] is highly resistant to these pathogens (Andersen, 1971; Jones and Strider, 1979; Lipschutz, 1965; Torres, 1963) and is a promising source of resistance genes for Zinnia breeding programs.

Crosses between $Z$. angustifolia $(2 n=2 x=$ $22)$ and $Z$. violacea $(2 n=2 x=24)$ yield infertile allodiploids $(2 n=2 x=23)$ (Boyle and Stimart, 1982; Terry-Lewandowski et al., 1984). Partially fertile, true-breeding allotetraploids $(2 n=4 x=46)$ have been produced by

Received for publication 16 Nov. 1995. Accepted for publication 17 Apr. 1996. Publication 3180 of the Massachusetts Agricultural Experiment Station. We wish to acknowledge partial support of this investigation by a grant awarded by The Fred C. Gloeckner Foundation. The cost of publishing this paper was defrayed in part by the payment of page charges. Under postal regulations, this paper therefore must be hereby marked advertisement solely to indicate this fact. treating allodiploids with colchicine (Boyle and Stimart, 1982; Terry-Lewandowski et al., 1984). Allotetraploids of $Z$. angustifolia and $Z$. violacea have been given the collective name Z. marylandica (Spooner et al., 1991). Terry-Lewandowski and Stimart (1983) found that $Z$. marylandica plants displayed high levels of resistance to $A$. zinniae and $E$. cichoracearum, and moderate to high levels of resistance to $X$. campestris pv. zinniae. Boyle (1996) obtained $\mathrm{BC}_{1}$ hybrids when $Z$. marylandica was crossed with autotetraploid forms of $Z$. angustifolia $(2 n=4 x=44)$ and $Z$. violacea $(2 n=4 x=48)$. Our objective for this study was to determine the reactions of $\mathrm{BC}_{1}$ plants to A. zinniae, E. cichoracearum, and $X$. campestris pv. zinniae.

\section{Materials and Methods}

Plant material. Thirteen Zinnia accessions were used for this study (Table 1). The parentage of $Z$. angustifolia $\mathrm{A} 88 \mathrm{C}, Z$. violacea $\mathrm{V} 86 \mathrm{C}$, and $Z$. marylandica $\mathrm{M} 1 \mathrm{C}$ and $\mathrm{M} 2 \mathrm{C}$, and the methods used to produce these lines, were reported previously (Boyle, 1996). Four BC families were produced by crossing lines M1C and M2C (as females) with A88C and V86C. Henceforth, the parental material will be referred to by their genomic formulas instead of their chromosome numbers (Table 1).

Cultural procedures. Seeds were sown in plastic bedding plant trays $(54.5 \mathrm{~cm}$ long $\times 28$ $\mathrm{cm}$ wide $\times 6 \mathrm{~cm}$ deep). The propagation medium was maintained at $\approx 22{ }^{\circ} \mathrm{C}$ by bottom heat. Seedlings were transplanted into plastic cell-packs (eight packs per flat and six cells per pack), using one seedling per $92-\mathrm{cm}^{3}$ cell. A commercial soilless mix (Fafard Growing Mix No. 2; Conrad Fafard, Springfield, Mass.) was used for sowing seed and transplanting.

Plants in the glasshouse were fertilized at each irrigation with $20 \mathrm{~N}-4.3 \mathrm{P}-16.6 \mathrm{~K}$ at 200 $\mathrm{mg} \mathrm{N} / \mathrm{L}$. The field plot used in Expt. 2 was amended with $10 \mathrm{~N}-4.3 \mathrm{P}-8.3 \mathrm{~K}$ at $50 \mathrm{~g} \cdot \mathrm{m}^{-2}$ before planting, and was fertilized twice (once in July and again in August) with 20N-4.3P$16.6 \mathrm{~K}$ at $300 \mathrm{mg} \mathrm{N} / \mathrm{L}$.

Glasshouse temperature setpoints were 18/ $21 / 23{ }^{\circ} \mathrm{C}$ (heat/vent/exhaust). Actual glasshouse air temperatures in Expts. 1 and 3 were monitored with a LI-1000 datalogger (LI-COR, Lincoln, Neb.) equipped with an aspirated LI1000-16 thermistor. The datalogger was configured with a sampling interval of $60 \mathrm{~s}$ and recorded mean temperatures at 1-h intervals. Shading compound (Kool Ray; Continental Products Co., Euclid, Ohio) was applied to the glass to maintain photosynthetic flux at $\leq 1200$ $\mu \mathrm{mol} \cdot \mathrm{m}^{-2} \cdot \mathrm{s}^{-1}$. Field plot temperatures (Expt. 2) were not recorded. Relative humidity (RH) was measured with a hygrometer (model 227059; Bacharach Instrument Co., Pittsburgh). All experiments were performed under natural daylengths (lat. $42^{\circ} 22.5^{\prime} \mathrm{N}$ ).

Reactions to Alternaria zinniae (Expt. 1). Seed were sown on 14 Apr. 1991. Five-weekold seedlings were planted in a $1.1 \times 14.0-\mathrm{m}$ glasshouse raised bed that was filled with a soil-based growing medium (3 sphagnum peat : 1 coarse perlite : 2 coarse, loamy, mixed mesic Typic Fragiochrept). The bed was steampasteurized $\left(\approx 80^{\circ} \mathrm{C}\right.$ for $\left.30 \mathrm{~min}\right) 1$ week before planting. The 12 entries were arranged in a randomized complete-block design with three blocks and one plot per block. Each plot consisted of 10 plants (two rows with five plants per row). Plants were spaced at a distance of 15 $\mathrm{cm}$ within rows and $30 \mathrm{~cm}$ between rows.

A single-spore isolate of A. zinniae obtained locally from diseased $Z$. violace $a$ plants was used for inoculum. The fungus was cultured on carrot agar (200 g homogenized carrots and $15 \mathrm{~g}$ Difco Bacto-agar/L; Difco, Detroit) and incubated for 8 days in a growth chamber set at $25 \pm 2{ }^{\circ} \mathrm{C}$ and providing $\approx 35$ $\mu \mathrm{mol} \cdot \mathrm{m}^{-2} \cdot \mathrm{s}^{-1}$ photosynthetic photon flux for $12 \mathrm{~h}$ daily from cool-white fluorescent lamps. Inoculum was prepared by gently scraping the surface of four petri plates with a spatula and washing the contents into $1 \mathrm{~L}$ of sterile distilled water containing $1 \mathrm{~mL}$ Tween 20/L (polyoxyethylene sorbitan monolaurate). The final concentration of the inoculum (determined by dilution-plating) was $\approx 1.2 \times 10^{3}$ colony-forming units (cfu)/mL. On 28 May, inoculum was applied with a pressurized hand sprayer onto the upper and lower leaf surfaces of each plant. Immediately after inoculation, a moist chamber was created by covering the ground bed with a white (0.1-mm-thick) polyethylene sheet. The polyethylene sheet was supported by two wires running parallel to the sides of the ground bed that were installed $1 \mathrm{~m}$ above the growing medium surface. Plants were misted at 2 -h intervals to maintain a high $(>95 \%) \mathrm{RH}$ in the moist chamber (Terry- 
Breeding, Cultivars, Rootstocks, \& Germplasm Resources

Table 1. Zinnia accessions used for study and their chromosome numbers, genomic formulas, and sources.

\begin{tabular}{|c|c|c|c|}
\hline $\begin{array}{l}\text { Breeding line, } \\
\text { cultivar, or hybrid }\end{array}$ & $\begin{array}{c}\text { Chromosome } \\
\text { no. } \\
(2 n)\end{array}$ & $\begin{array}{l}\text { Genomic } \\
\text { formula }^{z}\end{array}$ & Source $^{y}$ \\
\hline Z. angustifolia Classic & 22 & AA & BU \\
\hline Linearis White & 22 & AA & SI \\
\hline A88C & 44 & AAAA & MA \\
\hline Z. violacea Canary Bird & 24 & VV & $\mathrm{BO}$ \\
\hline Thumbelina Mini-Pink & 24 & VV & $\mathrm{BO}$ \\
\hline V86C & 48 & VVVV & MA \\
\hline Z. marylandica Rose Pinwheel & 46 & AAVV & BU \\
\hline M1C & 46 & AAVV & MA \\
\hline $\mathrm{M} 2 \mathrm{C}$ & 46 & AAVV & MA \\
\hline $\mathrm{BC}_{1}:$ Z. marylandica $\mathrm{M} 1 \mathrm{C} \times Z$ Z angustifolia $\mathrm{A} 88 \mathrm{C}$ & $45^{\mathrm{x}}$ & AAAV & MA \\
\hline $\mathrm{BC}_{1}:$ Z. marylandica $\mathrm{M} 2 \mathrm{C} \times Z$ Z. angustifolia $\mathrm{A} 88 \mathrm{C}$ & $45^{\mathrm{x}}$ & AAAV & MA \\
\hline $\mathrm{BC}_{1}: Z$. marylandica $\mathrm{M} 1 \mathrm{C} \times Z$. violacea $\mathrm{V} 86 \mathrm{C}$ & $47^{\mathrm{x}}$ & AVVV & MA \\
\hline $\mathrm{BC}_{1}:$ Z. marylandica $\mathrm{M} 2 \mathrm{C} \times Z$. violacea $\mathrm{V} 86 \mathrm{C}$ & $47^{\mathrm{x}}$ & AVVV & MA \\
\hline
\end{tabular}

${ }^{\mathrm{Z}} \mathrm{A}=Z$. angustifolia $(n=11) ; \mathrm{V}=Z$. violacea $(n=12)$.

${ }^{\mathrm{y}} \mathrm{BO}=$ Bodger Seeds, Lompoc, Calif.; $\mathrm{BU}=\mathrm{W}$. Atlee Burpee Co., Warminster, Pa.; MA = Univ. of Massachusetts, Amherst; SI = Sutton and Sons (India) Pvt.,Calcutta, India.

${ }^{\mathrm{x}} \mathrm{Chromosome} \mathrm{numbers} \mathrm{and} \mathrm{genomic} \mathrm{formulas} \mathrm{for} \mathrm{BC}_{1}$ plants are expected values and are not based on actual chromosome counts.

Lewandowski and Stimart, 1983). The moist chamber was removed $24 \mathrm{~h}$ after inoculation.

Disease reactions were assessed 14 days after inoculation. We used a 0 to 2 disease index scale similar to that used by TerryLewandowski and Stimart (1983): $0=$ no symptoms on leaves or stems; $1=$ small necrotic flecks $(<2 \mathrm{~mm}$ in diameter) on leaves and stems but no sporulation; and $2=$ large, sporulating lesions ( $\geq 2 \mathrm{~mm}$ in diameter) on leaves and stems. Plants with a disease index value $\leq 1$ were scored as resistant, and those with a value $>1$ were scored as susceptible.

Reactions to Erysiphe cichoracearum (Expt. 2). Seeds were sown on 1 June 1988. Fourweek-old seedlings were planted in a field plot consisting of a coarse, loamy, mixed mesic Typic Fragiochrept. The 13 entries were arranged in a randomized complete-block design with two blocks and one plot per block. Each plot contained 20 seedlings (four rows with five seedlings per row). Plants were spaced $30 \mathrm{~cm}$ apart.

Plants of Z. violace a severely infected with E. cichoracearum were harvested from the glasshouse. Field-grown plants were inoculated twice (4 and 6 Sept.) by shaking the infected plants over the canopy to release conidia. Disease reactions were assessed 21 days after the second inoculation. Plants with abundantly sporulating mildew colonies on the leaves and stems were scored as susceptible, and those devoid of mildew colonies were scored as resistant.

Reactions to Xanthomonas campestris $p v$. zinniae (Expt. 3). Seeds were sown on 17 Apr. 1989. Five-week-old seedlings were planted in a $1.1 \times 14.0-\mathrm{m}$ glasshouse raised bed that had been steam-pasteurized $\left(\approx 80{ }^{\circ} \mathrm{C}\right.$ for 30 min) 4 days earlier. The 13 entries were arranged in a randomized complete-block design with three blocks and one plot per block. Each plot consisted of 10 plants (two rows with five plants per row). Rows were spaced $30 \mathrm{~cm}$ apart and plants were spaced $15 \mathrm{~cm}$ apart within rows.

Xanthomonas campestris pv. zinniae was recovered from diseased $Z$. violacea plants acquired locally. The bacterium was identi- fied using standard morphological, biochemical, and physiological tests (Schaad, 1988). Pathogenicity was confirmed by inoculating $Z$. violace $a$ plants with the bacterium. Bacteria were grown on sucrose-peptone agar (Lelliott and Stead, 1987) and were incubated for $48 \mathrm{~h}$ in a growth chamber kept at $27 \pm 1^{\circ} \mathrm{C}$. Inoculum was prepared by flooding pure cultures of $X$. campestris pv. zinniae with sterile distilled water. The final concentration of the inoculum (determined by dilution-plating) was $\approx 1.8 \times$ $10^{8} \mathrm{cfu} / \mathrm{mL}$. On 29 May, inoculum was applied to the upper leaf surfaces of each plant using a pressurized hand sprayer. A moist chamber was created by covering the ground bed with a sheet of white polyethylene, as described in Expt. 1. Plants remained in the moist chamber from $3 \mathrm{~h}$ before until $24 \mathrm{~h}$ after inoculation (Jones and Strider, 1979). Plants were misted at 3-h intervals to maintain a high $(>95 \%) \mathrm{RH}$ in the chamber.

Disease reactions were assessed 21 days after inoculation. The two leaves at the fourth node from the base were collected from the main stem of each plant, and the number of necrotic lesions with chlorotic margins was recorded. Leaf area differed significantly among the entries (Boyle, 1996), and to correct for these differences, the number of lesions per $10 \mathrm{~cm}^{2}$ of leaf area was determined for each plant and entry. Leaf area was measured with an area meter (model LI-3000A; LI-COR). The percentage of plants showing disease symptoms (necrotic lesions) was calculated for each entry.

\section{Results and Discussion}

Experiment 1. During the 14 days from inoculation to disease assessment, glasshouse air averaged $19.0 \pm 1.4^{\circ} \mathrm{C}$ at night and $23.6 \pm$ $2.9^{\circ} \mathrm{C}$ during the day, and ranged from 17 to $33^{\circ} \mathrm{C}$. Entries varied in their responses to $A$. zinniae (Table 2). All three Z. violacea entries were susceptible to the pathogen. Inoculated plants of $Z$. violacea formed large, sporulating leaf lesions that frequently coalesced into necrotic patches, and stem lesions often girdled the stems, causing shoot tip dieback. Entries of
Z. angustifolia, Z. marylandica, and the $\mathrm{BC}_{1}$ hybrids contained from $93 \%$ to $100 \%$ resistant plants (Table 2). Resistant plants produced small, nonsporulating lesions on the leaves and stems, or were devoid of lesions.

One plant of Z. angustifolia 'Classic' developed several large, sporulating leaf lesions and was classified as susceptible. Spores were collected and recultured on carrot agar (as described previously), which confirmed the presence of A. zinniae. Neither Lipschutz (1965) nor Terry-Lewandowski and Stimart (1983) reported any cases of susceptibility to A. zinniae in Z. angustifolia. Our results demonstrate that $Z$. angustifolia 'Classic' is segregating for resistance to alternaria blight. CommercialZ. angustifolia cultivars, such as 'Classic', are open-pollinated and consist of highly self-incompatible genotypes (Boyle and Stimart, 1986). Although phenotypic variation within cultivars is limited, considerable genetic variation would be expected to occur within cultivars due to allogamy. Previous studies (Boyle et al., 1987; Boyle and Stimart, 1989a) have shown that $Z$. angustifolia cultivars also segregate for genes affecting seedling emergence, plant morphology, and flowering.

The two $\mathrm{BC}_{1}$ entries derived from crossing $Z$. marylandica with $Z$. violacea yielded $93 \%$ to $100 \%$ resistant plants (Table 2). Two plants in one $\mathrm{BC}_{1}$ family (M1C $\times$ V86C) formed large, sporulating leaf and stem lesions and were classified as susceptible; all other plants in these two $\mathrm{BC}_{1}$ families were classified as resistant. These results suggest that one $Z$. angustifolia genome in $\mathrm{BC}_{1}$ allotetraploids (AVVV) is sufficient to confer a high level of resistance to A. zinniae.

Primary inoculum of A. zinniae comes frominfected zinnia seed or infested soil (Baker and Davis, 1950; Dimock and Osborn, 1943; Neergaard, 1945). Current control procedures include treating zinnia seeds with hot water (Baker and Davis, 1950), disinfesting the growing medium using steam or chemical fumigants, and applying chemical eradicants. However, these practices increase production costs and, in some cases, pose health risks. Genetic resistance to $A$. zinnia offers a cost-effective, safe alternative to the control methods used currently.

Experiment 2. Entries were either $100 \%$ resistant or $100 \%$ susceptible to $E$. cichoracearum (Table 2). The threeZ. violacea entries were highly susceptible to powdery mildew and contained numerous, sporulating mildew colonies on the leaves and stems. In contrast, the $Z$. angustifolia, Z. marylandica, and $\mathrm{BC}_{1}$ entries were devoid of mildew colonies on all plant parts. The responses we observed when Z. angustifolia, Z. marylandica, and $Z$. violacea were inoculated with $E$. cichoracearum are essentially identical with those reported by Terry-Lewandowski and Stimart (1983).

Erysiphe cichoracearum has a wide host range, and the strain that infects zinnias also attacks many other Compositae species (Schmitt, 1955). Although Baker and Locke (1946) demonstrated that seed transmission of 
Table 2. Disease reactions of Zinnia angustifolia, Z. violacea, and their $\mathrm{F}_{1}$ and $\mathrm{BC}_{1}$ hybrids to Alternaria zinniae (alternaria blight), Erysiphe cichoracearum (powdery mildew), and Xanthomonas campestris pv. zinniae (bacterial leaf and flower spot).

\begin{tabular}{|c|c|c|c|c|c|c|}
\hline \multirow[b]{2}{*}{ Entry } & \multirow[b]{2}{*}{$\begin{array}{l}\text { Genomic } \\
\text { formula }^{2}\end{array}$} & \multicolumn{2}{|c|}{ A. zinniae } & \multirow{2}{*}{$\begin{array}{c}\text { E. cichoracearum } \\
\text { Resistant } \\
\text { plants }(\%)^{\mathrm{w}}\end{array}$} & \multicolumn{2}{|c|}{ X. campestris pv. zinniae } \\
\hline & & $\begin{array}{c}\text { Disease } \\
\text { index }^{y}\end{array}$ & $\begin{array}{c}\text { Resistant } \\
\text { plants }(\%)^{\mathrm{x}}\end{array}$ & & $\begin{array}{c}\text { No. lesions/ } \\
10 \mathrm{~cm}^{2} \text { leaf area }\end{array}$ & $\begin{array}{c}\text { Symptomless } \\
\text { plants }(\%) \\
\end{array}$ \\
\hline \multicolumn{7}{|c|}{ Z. angustifolia } \\
\hline Classic & AA & $0.6 \pm 0.6$ & 97 & 100 & $0.0 \pm 0.0$ & 100 \\
\hline Linearis White & AA & $0.8 \pm 0.4$ & 100 & 100 & $0.0 \pm 0.0$ & 100 \\
\hline A88C & AAAA & $0.8 \pm 0.4$ & 100 & 100 & $0.0 \pm 0.0$ & 100 \\
\hline \multicolumn{7}{|c|}{ Z. violacea } \\
\hline Canary Bird & VV & $2.0 \pm 0.0$ & 0 & 0 & $6.0 \pm 4.1$ & 0 \\
\hline Thumbelina Mini-Pink & VV & $2.0 \pm 0.0$ & 0 & 0 & $4.4 \pm 2.9$ & 0 \\
\hline V86C & VVVV & $2.0 \pm 0.0$ & 0 & 0 & $5.4 \pm 3.0$ & 0 \\
\hline \multicolumn{7}{|c|}{ Z. marylandica } \\
\hline Rose Pinwheel & AAVV & $0.9 \pm 0.4$ & 100 & 100 & $0.3 \pm 0.6$ & 64 \\
\hline M1C & AAVV & $1.0 \pm 0.0$ & 100 & 100 & $0.1 \pm 0.2$ & 70 \\
\hline $\mathrm{M} 2 \mathrm{C}$ & AAVV & $0.7 \pm 0.5$ & 100 & 100 & $0.2 \pm 0.6$ & 63 \\
\hline \multicolumn{7}{|c|}{ Z. marylandica $\times Z$. angustifolia $\left(B C_{l}\right)$} \\
\hline $\mathrm{M} 1 \mathrm{C} \times \mathrm{A} 88 \mathrm{C}$ & AAAV & -- & -- & 100 & $0.1 \pm 0.3$ & 96 \\
\hline $\mathrm{M} 2 \mathrm{C} \times \mathrm{A} 88 \mathrm{C}$ & AAAV & $0.6 \pm 0.5$ & 100 & 100 & $0.1 \pm 0.1$ & 90 \\
\hline \multicolumn{7}{|c|}{ Z. marylandica $\times \mathrm{Z}$. violacea $\left(B C_{l}\right)$} \\
\hline $\mathrm{M} 1 \mathrm{C} \times \mathrm{V} 86 \mathrm{C}$ & AVVV & $0.8 \pm 0.4$ & 100 & 100 & $7.0 \pm 6.1$ & 0 \\
\hline $\mathrm{M} 2 \mathrm{C} \times \mathrm{V} 86 \mathrm{C}$ & AVVV & $0.8 \pm 0.6$ & 93 & 100 & $5.0 \pm 3.0$ & 0 \\
\hline
\end{tabular}

${ }^{\mathrm{z}} \mathrm{A}=Z$. angustifolia $(n=11) ; \mathrm{V}=Z$. violacea $(n=12)$.

${ }^{\mathrm{y}}$ Mean \pm SD. Disease index: $0=$ no symptoms on leaves or stems; $1=$ small necrotic flecks $(<2$ mm in diameter $)$ on leaves and stems but no sporulation; and $2=$ large, sporulating lesions ( $\geq 2 \mathrm{~mm}$ in diameter) on leaves and stems.

${ }^{x}$ The percentage of plants within each entry having a disease index of 0 or 1 .

whe percentage of plants within each entry that were devoid of mildew colonies on leaves and stems.

${ }^{\vee}$ Mean \pm SD. Lesions were counted on two leaves at the fourth node from the base of the main stem.

cleistothecia was possible, primary inoculum of E. cichoracearum for zinnia infections is likely to come from wild or cultivated Compositae growing nearby. Currently, the only practical method for controlling powdery mildew on zinnias is by applying chemical eradicants. Our data show that the levels of resistance present in $Z$. angustifolia, $Z$. marylandica, and the $\mathrm{BC}_{1}$ entries are effective in controlling powdery mildew (Table 2 ). These results suggest that presence of one $Z$. angustifolia genome in $\mathrm{BC}_{1}$ allotetraploids (AVVV) is enough to confer resistance to $E$. cichoracearum.

Experiment 3. During the 21 days from inoculation to disease assessment, glasshouse air averaged $18.9 \pm 1.2^{\circ} \mathrm{C}$ at night and $22.9 \pm$ $2.5^{\circ} \mathrm{C}$ during the day, and ranged from 15 to 33 ${ }^{\circ} \mathrm{C}$. The entries differed in the number of lesions per $10 \mathrm{~cm}^{2}$ leaf area and the percentage of symptomless plants (Table 2). Lesions were absent on all plants of the three $Z$. angustifolia entries (Table 2). The percentage of plants devoid of disease symptoms ranged from $64 \%$ to $96 \%$ in the three $Z$. marylandica lines and the two $\mathrm{BC}_{1}$ families derived from $Z$. angustifolia $\mathrm{A} 88 \mathrm{C}$ (AAAV). All of the plants in the three $Z$. violace $a$ accessions and two $\mathrm{BC}_{1}$ families derived from $Z$. violacea V86C (AVVV) exhibited disease symptoms, averaging 4.4 to 7.0 lesions per $10 \mathrm{~cm}^{2}$ leaf area (Table 2). The disease responses reported here for $Z$. angustifolia and $Z$. violacea agree with those reported previously (Jones and Strider, 1979; Terry-Lewandowski and Stimart, 1983).

The results (Table 2) demonstrate the effect of gene dosage on resistance of tetraploid zinnias to $X$. campestris pv. zinniae. The autotetraploid line of $Z$. angustifolia (AAAA) was completely resistant, $\mathrm{BC}_{1}$ allotetraploids with three $Z$. angustifolia genomes (AAAV) and $\mathrm{F}_{1}$ allotetraploids with two $Z$. angustifolia genomes (AAVV) were highly resistant, and $\mathrm{BC}_{1}$ allotetraploids with one $Z$. angustifolia genome (AVVV) and autotetraploid $Z$. violacea (VVVV) were moderately to highly susceptible to bacterial leaf and flower spot. Thus, a minimum of two $Z$. angustifolia genomes is necessary to confer a high level of resistance to $X$. campestris pv. zinniae in tetraploid zinnias.

Bacterial leaf and flower spot of zinnia was first reported in North America in 1972 (Sleesman et al., 1973) and has since become a major disease of $Z$. violacea. Primary inoculum of $X$. campestris pv. zinniae is chiefly or exclusively from infected seed (Strider, 1979a). Presence of a few infected seed in a seed package may yield $>90 \%$ infected seedlings due to preemergence spread of the pathogen (Strider, 1979a). These conditions can result in substantial plant losses for bedding plant growers. It is possible to control this disease with seed treatments (Strider, 1979b, 1980), but disease control is difficult once seedlings or mature plants become infected. Hence, genetic resistance to this pathogen is highly desirable.

Zinnia angustifolia manifests high levels of resistance to A. zinniae, E. cichoracearum, and $X$. campestris pv. zinniae (Table 2), but present-day cultivars of this species do not exhibit the diversity in flower size and ray floret colors displayed by $Z$. violacea cultivars (Boyle and Stimart, 1989b). BC $_{1}$ hybrids of $Z$. marylandica and tetraploid $Z$. violacea (AVVV) have larger capitula, more ray florets, and a greater diversity of floral pigments than either $Z$. angustifolia or Z. marylandica (Boyle, 1996), and are nearly as resistant as $Z$. angustifolia to $A$. zinniae and $E$. cichoracearum (Table 2). Hence, in the $\mathrm{BC}_{1}$ generation, it has been possible to combine the disease resistance of Z. angustifolia with many of the ornamental features of $Z$. violacea. Unfortunately, $\mathrm{BC}_{1}$ hybrids of $Z$. marylandica and tetraploid Z. violacea are similar to $Z$. violacea in their reactions to bacterial leaf and flower spot (Table 2). Further breeding will be required to combine high levels of resistance to $X$. campestris pv. zinniae with the ornamental characteristics of $Z$. violacea.

\section{Literature Cited}

Andersen, K. 1971. The behavior of powdery mildew conidia (Erysiphe cichoracearum) on the leaves of resistant and susceptible species of Zinnia. MS Thesis, Pennsylvania State Univ., University Park.

Baker, K.F. and L.H. Davis. 1950. Some diseases of ornamental plants in California caused by species of Alternaria and Stemphylium. Plant Dis. Rptr. 34:403-413.

Baker, K.F. and W.F. Locke. 1946. Perithecia of powdery mildew on Zinnia seed. Phytopathology 36:379-380.

Boyle, T.H. 1996. Backcross hybrids of Zinnia angustifolia and Z. violacea: Embryology, morphology, and fertility. J. Amer. Soc. Hort. Sci. 121:27-32.

Boyle, T.H. and D.P. Stimart. 1982. Interspecific hybrids of Zinnia elegans Jacq. and Z. angustifolia HBK: Embryology, morphology and powdery mildew resistance. Euphytica 31:857-867.

Boyle, T.H. and D.P. Stimart. 1986. Self-incompatibility and interspecific incompatibility: Relationships in intra- and interspecific crosses of Zinnia elegans Jacq. and Z. angustifolia HBK (Compositae). Theor. Appl. Genet. 73:305-315.

Boyle, T.H. and D.P. Stimart. 1989a. Effect of Zinnia angustifolia $\mathrm{HBK}$ genotype on morphology and flowering of Z. angustifolia $\times Z$. elegans Jacq. hybrids. Euphytica 44:73-79.

Boyle, T.H. and D.P. Stimart. 1989b. Anatomical 


\section{Breeding, Cultivars, Rootstocks, \& Germplasm Resources}

and biochemical factors determining ray floret color of Zinnia angustifolia, Z. elegans, and their interspecific hybrids. J. Amer. Soc. Hort. Sci. 114:499-505.

Boyle, T.H., D.P. Stimart, and G.R. Bauchan. 1987. Influence of Zinnia angustifolia HBK genotype on embryonic and vegetative development of $Z$. angustifolia $\times$ Z. elegans Jacq. interspecific hybrids. Theor. Appl. Genet. 73:716-723.

Dimock, A.W. and J.H. Osborn. 1943. An Alternaria disease of zinnia. Phytopathology 33:372-381.

Jones, J.J. and D.L. Strider. 1979. Susceptibility of zinnia cultivars to bacterial leaf spot caused by Xanthomonas nigromaculans $\mathrm{f}$. sp.zinniae. Plant Dis. Rptr. 63:449-453.

Lelliott, R.A. and D.E. Stead. 1987. Methods for the diagnosis of bacterial diseases of plants. Blackwell Scientific, Oxford, England.

Lipschutz, L. 1965. The resistance of Zinnia species to Alternaria zinniae Pape. MS Thesis, Pennsyl- vania State Univ., University Park.

McVaugh, R. 1984. Flora novo-galiciana: A descriptive account of the vascular plants of western Mexico. Vol. 12: Compositae. Univ. of Michigan, Ann Arbor.

Neergaard, P. 1945. Danish species of Alternaria and Stemphylium. Oxford Univ., London.

Schaad, N.W. 1988. Laboratory guide for identification of plant pathogenic bacteria. 2nd ed. Amer. Phytopathol. Soc., St. Paul, Minn.

Schmitt, J.A. 1955. The host specialization of Erysiphe cichoracearum from zinnia, phlox, and cucurbits. Mycologia 47:688-701.

Sleesman, J., D.G. White, and C.W. Ellett. 1973. Bacterial leaf spot of zinnia: A new disease in North America. Plant Dis. Rptr. 57:555-557.

Spooner, D.M., D.P. Stimart, and T.H. Boyle. 1991. Zinnia marylandica (Asteraceae: Heliantheae), A new disease-resistant ornamental hybrid. Brittonia 43:7-10.
Strider, D.L. 1979a. Detection of Xanthomonas nigromaculans f.sp. zinniae in zinnia seed. Plant Dis. Rptr. 63:869-873.

Strider, D.L. 1979b. Eradication of Xanthomonas nigromaculans f.sp. zinniae in zinnia seed with sodium hypochlorite. Plant Dis. Rptr. 63:873876.

Strider, D.L. 1980. Control of bacterial leaf spot of zinnia with captan. Plant Dis. 64:920-922.

Terry-Lewandowski, V.M. and D.P. Stimart. 1983. Multiple resistance in induced amphiploids of Zinnia elegans and Z. angustifolia to three major pathogens. Plant Dis. 67:1387-1389.

Terry-Lewandowski, V.M., G.R. Bauchan, and D.P. Stimart. 1984. Cytology and breeding behavior of interspecific hybrids and induced amphiploids of Zinnia elegans and Zinnia angustifolia. Can. J. Genet. Cytol. 26:40-45.

Torres, A.M. 1963. Taxonomy of Zinnia. Brittonia $15: 1-25$. 